\title{
Standard Operating Procedure of Housekeeping Adaptation: The Development of Assessment Tools in Cleaning Bathroom Practices at Vocational High School
}

Nenden Rani Rinekasari, Yoyoh Jubaedah, Siti Nuraeni Sobariah, and Tati

Family Welfare Education Study Program, Universitas Pendidikan Indonesia, Bandung, Indonesia

\section{Abstract}

Work competencies in cleaning bathroom practices should be relevant to standard operating procedures housekeeping. Education and training institutions included vocational high school requires to developed an assessment tools that are suitable to the works in housekeeping department. It covers the preparatory, process, and results practice stages. This study attempts to adapt housekeeping standard operating procedures for assessment tools development, especially in cleaning bathroom practices at vocational high school. The research used analysis, design, development, implementation, and evaluation approach. Expert judgment was used to evaluate an assessment tool of cleaning bathroom practices that would be suitable to apply at vocational high school. The experts are the people whose have an expertise in the assessment and housekeeping aspects, also people who work as practitioners at housekeeping department. Findings show that the development assessment tools of cleaning bathroom practices with adapting housekeeping standard operating procedures that covers the preparatory, processes, and results stages is very appropriate for the practices. The aspects regarded on the preparatory stage include the ability to prepare the tools and materials. Job performance at cleaning bathroom practices is the process phase. The last is the results phase that cover the appearance of the product that met the criteria of housekeeping standard operating procedures.

Keywords: adaptation, housekeeping standard operating procedure, assessment tools, cleaning bathroom practices, vocational high school

\section{Introduction}

Vocational high school based on the 2003 National Education Regulation No. 20 is a secondary education who prepares students especially for works at a specific occupation. Vocational school (school students) prepared to students a productive human which can work with their area of expertise through the process of education. 
(resources) by raising the quality of the education. A graduate school is an important resources seeds that the quality of the graduates needs to be improved and also being competence coached through the learning imposed [2].

The learning process is a process that has the goal which expressed in formulation of ability or behavior. It is expected owned by students after completing the learning. An evaluation of students learning outcomes is a connection to instructional program. It should be to find whether or not the goal of teaching is achieved, and how the quality of the teaching and learning process carried out. In the process of learning, the assessment usually use by teachers to gain information continuously on student outcomes which they have achieved at school tuition. This means that judgment is not only addressed a particular field but also an overall aspect which includes the achievement of the level of knowledge, skill, attitudes and values [3].

Assessment is the collection of information process which is acquired to make a decision related to education policy, the quality of education programs, the quality of the curriculum, and the quality of teaching or the extent to which of knowledge which student has obtained from the teaching material which have been taught to them [6]. Instructional assessment have to be shaped in interaction between teachers and students, this action is an integrated learning. A key role of assessment is to provide a meaningful, authentic, and significant feedback, and also related to the real world to increase of the quality of student learning and instructional [19].

Assessment used as a reflection to recognize achievement of students, so that assessment is an important part of learning [2]. Department of Education of The states, Territories and Commonwealth of Australia stated that judgment as evidence used by learners and teachers to determine whether the learning facility was involved in learning, where the purpose of learning will be headed, and how the best ways to reach the goal [6]. Assessment technique and instrument should be adapted to the objectives and targets of assessment, situation, and environmental conditions, and also the basic competence that mentioned in curriculum [15].

The evaluation process is implemented to identify the students' ability in conducting practices. It includes their knowledge and skills simultaneously. The emphasis of the practices assessment located in the decision-making process which shown in the practices performance. The implementation of practices concerning not only the theory but also relate to knowledge and skill. It is required to apply and comparing the theory into the form of work and attitude response in conducting practices. Teachers can evaluate skill competencies using practice tests, projects or portfolio assessment [10]. The aspects of the learning assessment are three domains such as cognitive, affective 
and psychomotor. Skill competencies assessment is performed by direct observation of the student performances. The regulation of Education and Culture Minister from number 66 in 2013 states that educator judge the skill competencies through an assessment of the performance.

Performance assessment is an assessment that demanding students to demonstrate a certain competence using a test practices, project, and portfolio assessment [11]. The assessment obtained by using the instruments of the assessment is more authentic more than using a classical test. In other words, contain of the test is reflects the capability that needed in daily life practices [1].

The job assessment is one of an assessment that suggested from 2013 Curriculum. It is apply for measuring student learning competencies achievement. And also this was very helpful in determination of decision through observation, and it proper to use it to assess the relative competence students practices [12] Performance assessment that used is very demanding an observer to observing all ability to students aspects [2]. Performance assessment is done by some teachers in several schools, however, in SMK 45 Lembang, some teachers have difficulties in doing that.

SMK 45 Lembang is school of tourism and hospitality expertise which develop an accommodation hospitality program. They have hotel facilities that can be used by students to ease the learning process in the field of practices. The purpose of accommodation hospitality skills at SMK 45 Lembang is preparing a student with a skill and an attitude, so they will be competent in the hotel industry. One of basic competence that they must be mastery is cleaning bathroom.

On cleaning bathroom practices, students prepared to be a professional room attendant, thus teachers are required to appraise the outcome of students practice in accordance with housekeeping standard operating procedures. Cleaning bathroom use these as assessment tools need not only the rote and understanding aspect but also need use these assessment tools to measure students' job performance according to standard operating procedures. Standard operating procedures are some kind of operational procedure standard used as a guideline in a firm. It use to ensure that each work of any member of has been running in more effective and consistent, and could fulfill a standards and systematic [22].

The testing instrument of the practice is covering the preparation, process of working and result which adapted to standard assessment competencies [8]. Another research revealed that development of the assessment tool performance based competency on industrial practices consist the planning and execution of the practice in assessment [9]. 
The planning assessment consist the purpose and methods components, while the execution of the practice assessment consists of preparation, the collection, and decision components according to the standard of competence. Based on the first observation at SMK 45 Lembang, assessment tool on cleaning bathroom practices used do not meet the demands of standard operating procedures housekeeping competencies.

Housekeeping standard operating procedures should be adapted to develop the tool the competence of cleaning bathroom with the assessment brief and detail criteria. A judgment is expected to be raw reference or standards in assessing practices cleaning bathroom and also facilitate the teachers in objective assessment. The learning assessment is an important component because of their functions for measuring the purpose of learning and students competence achievement, especially in cleaning bathroom practice. The main purpose in this research is adapting a housekeeping standard operating procedures practices on the development of cleaning bathroom assessment tool, especially on (1) identification of a cleaning bathroom assessment tools that consist the preparatory, process and results of practices stages, (2) developing assessment tools of cleaning bathroom practices based on housekeeping standard operating procedures and (3) testing the assessment tools through the fit and proper test of expert judgment.

\section{Methods}

The methodology is research and development according to Borg and Gall [7] and the research model is ADDIE. It was chosen because the design based on a system which effective and efficient and also interactive on of the process, thus the evaluation every phase proceed the development for the next learning phase [21]. This ADDIE model consist analysis, design, development, implementation and evaluation stages [16]. This research uses analysis, design and development only. Researchers conduct testing empirically through expert judgment from the expert and practitioners. Participants involved were three person, they are the assessment and housekeeping expert, and housekeeping department practitioners. Research instruments are documents, assessment format sheets of cleaning bathroom practices with the form of affirmation scales such as a register of checks, and validation expert judgment format. Research Procedures are the preparation, the implementation, and finishing of instrument assessment stages. Data analysis techniques used are the reduction data form, presentation of data, the percentage and interpretation of data. 


\section{Results}

Assessment tool was used in SMK 45 Lembang consist a scale range of assessment form one to 5 score. However the decision of scoring and the assessment criteria on a judgment was less well defined. The score only posted on final score and it mention only competent student gain score over 100 , and contrary said incompetent for those score below 100, without any calculation score. The t job performance student on cleaning bathroom practice at the preparation, processes and results was not adapting housekeeping standard operating procedures. The form of assessment tool on cleaning bathroom practice originally is an assessment tool with 1-5 scale. It is transformed to the assessment scale form of affirmation with the form of lists as a check "yes" and "no" criteria. Yes mean positive answer $=1$, and a negative answer $=0$ for No.

The development of the preparatory stage of cleaning bathroom assessment aspects should be conducted thoroughly by combining trolley and filling up trolley preparation into 6 aspects of assessments. It consist the appearance of self-assessment; preparation of equipment, chemical, linen supplies, and guest supplies; also the use of personal protective equipment while conduct the cleaning bathroom practices. Every aspect of the assessment of had a variety indicator that adapting from housekeeping standard operating procedures in accordance with the recommendation of the experts.

The initial development considered a whole aspect of preparing a living room. It is converted to a process of cleaning bathroom stage only, by removing several assessment aspects such as stripping room, making bed, cleaning living room and fill on room boy report. Then it combines with the assessment aspects of entering the room and room in progress to be the aspect of the assessment of room in progress cleaning bathroom. The subsequent of development deprive an access to the room assessment aspects, because the formulation of indicators inconsistent with the housekeeping standard operating procedure. It concluded the whole aspects from entering to the room such as the way of entering and knocked on the door, also, cleaning tools sanitation aspect i.e. cleaned the toilet bowl, bathtub, and wash basin; furnished linen and guest supplies, and the last was cleaning the wall and the floor of the bathroom.

The stage of the result assessment tools of bathroom cleaning practices bathroom prior consist one assessment aspect namely treatment trolley, then it converted into two assessment aspects. It consist two aspects, they are the final check of the bathroom and the duration. The duration need approximately is 15 to 25 minutes.

Cleaning bathroom assessment tools developed into the form of affirmation scales assessment that has an affirmative answer with two criteria: yes and no. It used to 
evaluate students' performance through the observation. Instrument completeness of performance assessment tools is accordance in terms of construction and language legibility. Assessment components cover a preparation, process and result of practice stages, and also put down the scoring guidelines. The discussion of the results analysis of assessment tools cleaning bathroom practices based on housekeeping standard operating procedures, are

The identification assessment tools which was conducted through an assessment tool documentation of cleaning the bathroom practices in SMK was a 1 to 5 range scale of assessment. It is converted into the shape of the assessment of affirmation scale with a "yes" and "no" answer criteria. This criteria set with a midrange from 1 to ten values, so that teacher would probably easy to use it. The assessment scale can also thought that the affirmation (yes) or denial (no) to give a definite value [6]. Assessment tool is made in the form of a checklist column that used to assess the student performance. Assessment tool completeness components in school should be completed with the assessment requirement such as substance, executive construction and the legibility of language [10].

Assessment components in this research cover the preparatory stage, processes and results that suitable with the hotel standard operating procedures [9]. They said that the application of the assessment was covering a preparation, collecting, judging, deciding and moderation stages.

Analysis of the identification result of assessment tools was used in SMK 45 Lembang shows that it has two aspects of assessment such as prepared trolley and filling up trolley. Both aspects is unsuitable with the housekeeping standard operating procedure, and supposed to turn into six aspects of indicator assessment formulation that in accordance with hotel standard operating procedures. The aspect of this assessment is started from the appearance of self, preparation of equipment, chemical, linen and guest and supplies, also the personal protective equipment [20].

Research shows that the documentation of the assessment at this school has three aspect of assessment namely entering to the room, access to the room and room in progress. These stages of the process should be altered to fit the housekeeping standard operating procedure. The stage process of room in progress in accordance with hotel standard operating procedures should be started from entering the room (the way of how entering and knocked on the door of a guest room), cleaning of sanitation tools in the bathroom such as cleaning the toilet bowl, a bathtub, and wash basin, also furnishing the linen and guest supplies; and the last is cleaning a wall and a floor of the bathroom [18, 20]. 
The identification result through documentary of assessment tool show in treatment trolley. It have four indicators, such as 1) removal the trash, 2) savings a linen cover, 3) saving a chemical cover, and 4) cleaning an equipment. Those aspect is unsuitable with the housekeeping standard of operating procedure. Researchers conducted the improvements for this aspect of assessment, such as including the final checking and time duration. A series of all part of housekeeping are the final checking as the last examination and temporal duration [4].

\section{Discussion}

Analysis of assessment tool on cleaning bathroom practices show several disadvantages that should be to improve. The development of cleaning bathroom practice assessment tool analyses

The development of this aspect is the changes of assessment affirmation scale form. The scale to evaluate performance is a yes and no answer, which span 0-1 value. The assessment scale could be judged as affirmation for yes or denial for no. A judgment made in the form of checklist used to evaluate students' performance through observation or other shaped. This checklist are a written performance criteria; several list of activities, a description, a skills, a concept, a behavior, a process or attitude, which is observed by teachers [6].

\section{Result Analyses Assessment of Cleaning Bathroom Practices}

The development of assessment stage at school includes three rounds of judgment referring to hotel standard operating procedures. Preparation stage of cleaning bathroom practices based on housekeeping standard operating procedure

\subsection{Grooming}

The development on preparation assessment stage of cleaning bathroom practices which based on hotel standard operating procedures is started from the selfappearance. The purpose of this is the room boy or student has the professional appearance and also good looking. The aspect of the assessment of the self-appearance is very important [20]. It must be considered in terms of both mentally and physically, because the grooming is first thing that guests seeing. Thus, before cleaning bathroom 
practices, a room boy should be maintain the cleanliness and neatness of themselves from the hair to toe. The results of the experts validation on the development of assessment tools of cleaning bathroom practices to the self-appearance are categorized it is very appropriate with the minor revision. The recommendation or the revision is the addition of name tag.

\subsection{Cleaning equipment and chemical}

The development of the equipment preparations aspects being made is the use of a cleaning bathroom tools that suitable with the hotel standards operating procedures. It also provides the function of cleaning bathroom process and provided with the example of tool that used. The examples of the variety of devices used during the process of cleaning bathroom which suitable with its function and the process of cleaning bathroom [14, 18]. The cleaners devices or equipment are a carry caddie, a hand brush, a glass squeegee, a sponge, a bottle spray, a dry or cleaning cloth, a dust cloth, a toilet brush, a floor squeezer, a stick mop, bucket mop and drain pump.

The assessment of chemical aspect on the assessment tool of cleaning bathroom at school was not yet describe what kind of material will use in this practice. The development is including the suitable equipment with housekeeping standard operating procedures, such as a glass cleaner, a floor cleaner, a MPC, a Go Getter, a Porcelain Cleaner, a metal polish brass and air freshener [5, 7, 14].

\subsection{Linen and guest supplies}

The assessment tools on the preparatory stage of cleaning bathroom practices especially on linen and guests' supplies is unclear defined. The development to this aspect is elaborating the assessment indicator of linen and guest supplies that should be prepared by room boy or students. It must suitable with hotel standard operating procedures. For linen and the guest supplies aspects, the development is the completeness in the facilities of bathroom hotel. This is the reason for guest to staying longer. Students and room boy in preparing linen and guest supplies should work in effective time.) In preparing linen and guest supplies, the stock in trolley should be no deficiency and also can saving time [20]. Some linen and guest supplies that need to prepared are bath towel, face towel, and bath mat, while in the guest supplies equipment are bath soap, shampoo, bath foam, tooth brush and paste, toilet paper, shower cup and sanitary bag [20]. The results of the assessment tools validation on cleaning bathroom 
practices based on hotel standard operating procedures adopted in the preparatory stage is categorized in a very appropriate with the minor revision. Revisions given by both expert is the addition of comb in guest supplies.

\subsection{Personal protective equipment}

Cleaning bathroom practices is the work with risky situation because using several chemical cleaning materials. Due to this aspect, students and room boy should use the personal protective equipment to avoid the accident. The development of this aspects is including the personal protective equipment on cleaning bathroom practices that suitable with housekeeping standard operating procedures. Protective equipment should be used when practices are hand rubber gloves, mask, eye glasses, and penny loafers [5]. The validation results on an assessment tool of cleaning bathroom practices based on hotel standard operating procedures on this results of practices stage is categorized very reasonable without revision.

The results of the study documentation shows that an assessment tool which used in SMK 45 Lembang was made according to the process of preparing the guest bedroom, but not included the process of cleaning bathroom. This assessment tools are three aspects, such as entering the room, access to the room and room in progress.

Development of the assessment tool on the process of practices stage is changing the cleaning process as a whole in preparing a guest room into the process of cleaning bathroom. However, the access to the room is deprive because the formulation of the indicators unsuitable with housekeeping standard operating procedures. It combines two aspects namely entering assessment to the room and room in progress activities into one aspect of assessment. It is a room in progress of cleaning bathroom. The step is started from entering the room (by judging how the way of entering and knocked on the door of guest room); cleaning the sanitation tools in in a bathroom, such as cleaning the toilet bowl, bathtub, and wash basin; then furnishing linen and guest supplies, and finally is cleaning the wall and the floor of bathroom [13, 18].

The results of expert judgment that the development assessment tools cleaning bathroom based on housekeeping standard operating procedures is categorized a very appropriate assessment with the revision of minor. The recommendation and commentary from second expert on the indicators of the entering a room process is a room status.

Assessment tool used in the school at the practice result is one aspect of judgment. It is the treatment trolley aspect with four indicators, such as removal trash, saving a linen 
over, saving a chemical over, cleaning and equipping. The treatment trolley aspect and the indicator on assessment tool is unsuitable with the housekeeping standard operating procedures. Thus, the development is to change the aspect of the treatment trolley be the result of cleaning bathroom that consist the final check (examination) and timing. The final series of the cleaning bathroom process is the final checking or final checkpoint [4]. The validation on the result of practices is very reasonable to use with minor revision. Both experts suggest to change the timing from 5-7 minutes to 15-25 minutes duration.

For the assessment tool practices components which is developed already meet the requirements of the assessment, such as a substance, a construction and the language legibility, and communicative [10]. Finally, the assessment aspect performance as an instrument for must meet the requirements of a good assessment tool. It includes of three things assessment that suitable with housekeeping standard operating procedure, they are the preparation, processes and results practices.

\section{Conclusion}

The assessment tool of cleaning bathroom practice has an innovative pre-eminence since it is already developed with adapting job performance which included the housekeeping standard operating procedures.

The validation result of the assessment tools on cleaning bathroom practice is categorized as a very appropriate assessment by the experts. It means the assessment tools could be implemented in vocational high school at the time of practices. It consists of the conformity assessment format, substance, construction, and the language legibility refer to the housekeeping standard operating procedures.

At the preparatory stage, the development made consolidate from the two assessment aspects to six aspects of the assessment. The aspect of this assessment is started from the self-appearance or grooming, preparation of the equipment, chemical, linen, and guest supplies, also the use of personal protective equipment that suitable with housekeeping standard operating procedures. On the process stage, the development is made to consolidate two aspects of assessment, namely entering to the room and room in progress into six aspect of the assessment of the process. It begin from entering room, cleaning the toilet bowl, cleaning a bathtub, cleaning wash basin, furnishing the linen supplies and guest supplies, and finally, cleaning bathroom walls and floor in accordance with housekeeping standard operating procedures. At the results stage, the development is the change of the assessment from treatment trolley aspect into 
two aspects concerning the final examination and duration with approximately 15 to 25 minutes time according to housekeeping standard operating procedures

\section{Funding}

This work was supported by the Research, technology and higher school ministry.

\section{Acknowledgement}

The authors would like to thank their colleague for their contribution and support to the research. They are also thankful to all the reviewers who gave their valuable inputs to the manuscript and helped in completing the paper.

\section{Conflict of Interest}

The authors have no conflict of interest to declare.

\section{References}

[1] Agustini R dan Ningtyas K.F. (2014). Pengembangan Instrumen Penilaian Kinerja Siswa Untuk Mengakses Keterampilan Proses Dalam Praktikum Senyawa Polar dan Non Polar Kelas X SMA. UNESA Journal of Chemical Education, Vol 3 Nomor 03. pp 169-175.

[2] Anwar, Ramlawati \& Anggraini. (2017). Pengembangan Perangkat Penilaian Kinerja dan Sikap Pada Kinerja Praktikum Titrimetri dan Gravimetri SMK-SMTI Makasar. Jurnal Chemistry Education Review, Pendidikan Kimia PPs UNM, Vol 1 No 1, hlm 35-44.

[3] Arifin, Z. (2011). Evalusi Pembelajaran. Jakarta: Direktorat Jenderal Pendidikan Islam Kementrian Agama RI.

[4] Bagyono. (2009). ManajemenHousekeeping Hotel. Bandung: ALFABETA.

[5] Bagyono. (2010). Modul Menyiapkan Kamar untuk Tamu. Jakarta: Erlangga.

[6] Basuki dan Hariyanto. (2014). Asesmen Pembelajaran. Bandung: PT.Remaja Rosdakarya Offset.

[7] Darsono, A. (1999). Tata Graha Hotel(Housekeeping). Jakarta. Grasindo. 
[8] Jubaedah, Y. (2009). Model Penelitian Keahlian Tata Busana Berbasis Standar Kompetensi Nasional Di Sekolah Menengah Kejuruan. Program Studi Pengembangan Kurikulum Sekolah Pascasarjana Universitas Pendidikan Indonesia. Bandung.

[9] Jubaedah, Rohaeni \& Rinekasari. (2017). Development of Competency Based Assessment Model on Job Performance in Family Welfare Education Apprenticeship. Jurnal Inovasi pendidikan Kejuruan Teknologi. Vol XIII,

[10] Kemendikbud. (2014). Materi Pelatihan Guru Implementas Kurikulum 2013 Tahun Ajaran 2014/2015.Jakarta: Kementerian Pendidikan dan Kebudayaan.

[11] Kunandar. (2014).Penilaian Autentik, Penilaian Hasil Belajar Peserta Didik Berdasarkan Kurikulum 2013.Jakarta: Rajawali.

[12] Kusairi, Hardita dan Munfarida. (2016). Pengembangan Instrumen Performance Assessment Berbantuan Kompetensi pada Materi Optik, Kalor, dan Listrik. Jurnal Edu-Sains. Vol 5 Nomor 1.

[13] Perwani, S.Y. (1993).Teori dan Petunjuk Praktik Housekeeping untuk Akademi Perhotelan: Make Up Room. Jakarta: PT. Gramedia Pustaka Utama.

[14] Rumekso. (2008). Housekeeping Hotel PUBLIC AREA/HOUSEMAN SECTION. Yogyakarta: ANDI.

[15] Ruslan. (2005). Prinsip Dasar Evaluasi (Disampaikan Pada Diklat Guru Sekolah Dasar Mata Pelajaran Matematika). Makasar: Lembaga Penjamin Mutu Pendidikan Sulawesi Selatan.

[16] Robert, M.B. (2009). Instructional Design: The ADDIE. Aproach: Springer.

[17] Sukmadinata, N.S. (2011). Metode Penelitian Pendidikan. Bandung: PT. Remaja Rosdakarya.

[18] Sulastiyono. (2010).Teknik dan Prosedur Divisi Kamar Pada Bidang Hotel. Bandung: ALFABETA.

[19] Sundari. (2014). Model Pengembangan Asesmen Kinerja (Performance Assessment) Berbasis Nilai Karakter di SMP Kota Ternate Maluku Utara. Jurnal EduBio Tropika, Vol 2, No.1, 121- 186.

[20] Suwithi, N. (2008). Akomodasi Perhotelan. Jilid 2. Jakarta: Direktorat Pembinaan Sekolah Menengah Kejuruan.

[21] Widiana, W. (2016). Pengembangan Assessmen Proyek Dalam Pembelajaran IPA di Sekolah Dasar. Jurnal Pendidikan Indonesia, 5(2). doi:https://scholar.google. co.id/scholar?hl=en\&as_sdt=0\{\%\}2C5\&as_vis=1\&q=Pengembangan+assessment+ proyek+dalam+pembelajaran+ipa+di+sekolah+dasar+\{\%\}3Bpdf\&btnG=

[22] Winata. (2016). Perancangan Standard Operating Procedur (SOP) Pada Chocolab. Jurnal Manajemen dan Start-Up Bisnis. Vol 1, Nomor 1. 